\title{
Akses Informasi Pemustaka Tunanetra Pada Layanan Braille Corner Di Dinas Perpustakaan Dan Kearsipan Kota Jambi
}

\author{
1Oktarina Dwi Putri, Muhammad Rum² \\ ${ }_{1}$ Fakultas Adab, Universitas Islam Negeri Sulthan Thaha Saifuddin Jambi \\ ${ }_{2}$ Fakultas Adab, Universitas Islam Negeri Sulthan Thaha Saifuddin Jambi \\ Jalan Jambi - Muaro Bulian Km.16, Muaro Jambi, 36363 \\ e-mail:oktarinadwiputri579@gmail.com
}

\begin{abstract}
Introduction. This research is entitled Information Seeker Behavior of Blind Users in Braille Corner Services at the Jambi City Archives and Libraries Service, the purpose of this study is to determine the behavior of the blind in seeking information at the Jambi City Archives and Library Service. Information seeking behavior arises because of the need for information, so the higher the need for information, the higher the number of activities seeking information. Information behavior by users has its own pattern. Because each user will find the information they need differently, therefore the need for information is very important. From this difference, the writer is interested in studying "The Behavior of Information Seekers for the Braille Corner Service for Blind Users at the Jambi City Archives and Library Service".

Data Collection Method. This study uses a qualitative descriptive method in the form of case study research. Informants in researching 3 people, informants were selected based on purposive sampling. Data collection techniques in this study were observation, in-depth interviews and documentation, the subjects in this study were blind users who visited the Braille Corner service.

Data Analysis. Data analysis techniques in this study used data reduction, data presentation and drawing conclusions.

Result and Discusions. The results obtained from the search for information on Braille Corner services for blind users at the Jambi City Archives and Library Service are strongly influenced by Braille Corner service officers. The type of information that is often accessed by blind users at the Jambi City Archives and Library Service is the printed collection of Braille. Information obtained by blind users is used for their respective interests and is used for different purposes.
\end{abstract}

Keywords: Information Seeking Behavior, Blind, Public Library .

\begin{abstract}
ABSTRAK
Pendahuluan. Penelitian ini berjudul Perilaku Pencari Informasi Layanan Braille Corner Pemustaka Tunanetra di Dinas Kearsipan Dan Perpustakaan Kota Jambi, tujuan dari penelitian ini untuk mengetahui perilaku tunanetra dalam mencari informasi di Dinas Kearsipan Dan Perpustakaan Kota Jambi. Perilaku pencarian informasi muncul karena adanya kebutuhan akan informasi, Sehingga semakin tinggi kebutuhan informasi maka semakin tinggi pula jumlah kegiatan mencari informasi. Perilaku pencarian informasi oleh pemakai memiliki pola tersendiri. Sebab setiap pemakai akan berbeda-beda mencari informasi yang dibutuhkan, oleh karena itu kebutuhan akan infromasi menjadi hal yang sangat penting. Dari perbedaan inilah penulis tertarik mengkaji mengenai "Perilaku Pencari Informasi Layanan Braille Corner Pemustaka Tunanetra di Dinas Kearsipan dan Perpustakaan Kota Jambi”.

Metode Penelitian. Penelitian ini menggunakan metode Deskriktif Kualitatif dengan bentuk penelitian studi kasus. Infroman dalam penelitian berjumlah 3 orang, informan dipilih berdasarkan Purposive Sampling. Teknik pengumpulan data dalam penelitian ini adalah observasi,wawancara
\end{abstract}


mendalam dan dokumentasi, subjek dalam penelitian ini adalah pemustaka tunanetra yang berkunjung ke layanan Braille Corner.

Data analisis. Teknik analisis data dalam penelitian ini menggunakan reduksi data, penyajian data dan penarikan kesimpulan.

Hasil dan Pembahasan. Hasil yang diperoleh dari Pencarian Informasi Layanan Braille Corner Pemustaka Tunanetra Di Dinas Kearsipan Dan Perpustakaan Kota Jambi sangat dipengaruhi oleh petugas layanan Braille Corner. Jenis informasi yang sering diakses oleh pemustaka tunanetra di Dinas Kearsipan dan Perpustakaan Kota Jambi adalah koleksi tercetak Braille. Informasi yang didapat oleh pemustaka tunanetra digunakan untuk kepentingan masing-masing serta digunakan untuk keperluan yang berbeda-beda.

Kata kunci: Perilaku Pencarian Informasi, Tunanetra, Perpustakaan Umum .

\section{A. LATAR BELAKANG}

Perpustakaan merupakan tempat yang menyediakan berbagai koleksi informasi untuk memenuhi kebutuhan penggunanya. Perpustakaan juga diartikan sebagai unit kerja dari suatu badan atau lembaga tertentu yang mengelola bahan-bahan pustaka, baik berupa buku maupun non buku yang diatur secara sistematis menurut aturan tertentu sehingga dapat digunakan sebagai sumber informasi. Perpustakaan sebagai sumber informasi dituntut untuk memberikan informasi dengan layanan yang baik dan layak. Layanan perpustakaan harus didasarkan pada kebutuhan penggunanya, dengan kata lain menempatkan pengguna sebagai salah satu faktor penting yang mempengaruhi kebijakan pada suatu perpustakaan. Sedangkan menurut Rahayuningsih, pelayanan perpustakaan merupakan kegiatan memberikan layanan informasi kepada pengguna perpustakaan dengan menggunakan prinsip-prinsip dasar: (1) pelayanan bersifat universal, layanan tidak hanya diberikan kepada individu-individu tertentu, tetapi diberikan kepada pengguna secara umum, (2) pelayanan berorientasi pada pengguna dalam arti untuk kepentingan para pengguna bukan kepentingan pengelola, (3) menggunakan disiplin untuk menjamin keamanan dan kenyamanan dalam memanfaatkan perpustakaan, (4) sistem yang dikembangkan mudah, cepat dan tepat. Kegiatakan perpustakaan yang langsung dirasakan oleh pengguna pelayanan, karena pelayanan dianggap sebagai ujung tombak perpustakaan.

Ditinjau dari sisi kuantitas, jumlah orang buta di Indonesia di perkirakaan 1.5\% dari jumlah penduduk Indonesia atau sekitar 3 juta orang. Dengan jumlah yang signifikan tersebut, banyak media yang mencoba menfasilitasi mereka dengan informasi, diantaranya dengan penggunaan huruf braille, printer braille,dll. Timbulnya kesenjangan dalam perilaku pencari informasi muncul karena pengetahuan dan kebutuhan informasi yang diperlukannya dalam mencari informasi. Sehingga terdapat kemudahan keakuratan dalam mengakses informasi yang dibutuhkan yaitu kepuasan dan kenyamanan atas layanan yang diberikan oleh 
perpustakaan. Perilaku pencarian informasi muncul karena adanya kebutuhan akan informasi, Sehingga semakin tinggi kebutuhan informasi maka semakin tinggi pula jumlah kegiatan mencari informasi. Perilaku pencarian informasi oleh pemakai memiliki pola tersendiri. Sebab setiap pemakai akan berbeda-beda mencari informasi yang dibutuhkan, oleh karena itu kebutuhan akan infromasi menjadi hal yang sangat penting. Dari perbedaan inilah penulis tertarik mengkaji mengenai "Perilaku Pencari Informasi Layanan Braille Corner Pemustaka Tunanetra di Dinas Kearsipan dan Perpustakaan Kota Jambi”.

\section{B. TINJAUAN PUSTAKA}

Penelitian Kurnia Astari dengan judul Perilaku pencarian informasi pemustaka tunanetra dalam mengakses informasi di perpustakaan SAPDA Yogyakarta. Sama-sama menggunakan menggunakan metode penelitian deskriktif kualitatif, Penelitian Kurnia Astari sama-sama menggunakan bentuk penelitian studikasus. Sedangkan Perbedaan hasil penelitian jenis informasi Kurnia Astari dengan penelitian ini jenis informasi yang sering diakses oleh pemustaka adalah koleksi tercetak Braille. Perbedaan hasil penelitian jenis informasi Kurnia Astari dengan penelitian ini Sumber informasi yang sering di gunakan oleh pemustaka tunanetra adalah dengan menggunakan daftar koleksi perpustakaan, serta pemustaka bertanya kepada petugas layanan dalam penelusuran informasi. Penelitian Kurnia Astari tidak menggunakan Triangulasi sedangkan penelitian ini menggunakan Triangulasi.

Penelitian Abkarina musa'adah dengan judul Kebutuhan dan perilaku pencarian informasi pamakai tunanetra dalam mengakses informasi di perpustakaan Balai Rehabilitas Sosial Penganthi Temanggung dalam menggunakan metode penelitian samasama menggunakan metode deskriktif kualitatif. Penelitian Abkarina musa'adah dengan penelitian ini sama-sama menggunakan bentuk penelitian studikasus Penelitian Abkarina musa'adah dengan penelitian ini sama-sama menggunakan jenis dan sumber data primer dan sekunder. Sedangkan Perbedaan penelitian Teknik pengumpulan data dalam penelitian Abkarina musa'adah yaitu observasi dan wawancara mendalam. Hasil penelitian Abkarina musa'adah pemustaka lebih memilih mengakses menggunakan alat elektronik yaitu audio visual atau $p d f$, sceen reader dan software JAWS.

Penelitian Ricky Ansori dengan judul Perilaku pencarian informasi pemakai pada layanan perpustakaan Tunanetra Yayasan Mitra Netra Jakarta penelitian sama-sama menggunakan teknik pengumpulan data observasi,wawancara mendalam, dan 
dokumentasi. Penelitian Ricky Ansori dengan penelitian ini sama-sama menggunakan bentuk penelitian studikasus. Penelitian Ricky Ansori dengan penelitian ini sama-sama menggunakan metode penelitian deskriktif kualitatif. Sedangkan Perbedaan Ricky Ansori dengan penelitian ini adalah Penelitian Ricky Ansori menggunakan Kredibilitas penelitian yaitu Perpanjangan pengamatan dan Meningkatkan ketekunan Ricky Ansori dalam penelitiannya menggunakan Triangulasi yaitu Analisis kasus negative, Menggunakan bahan referensi, serta mengadakan member check.

\section{METODE PENELITIAN}

Pendekatan yang digunakan dalam penelitian ini adalah pendekatan kualitatif yaitu suatu prosedur penelitian yang menghasilkan data deskriptif berupa ucapan atau tulisan dan perilaku yang dapat diamati dari subyek itu sendiri.

Jenis penelitian ini bersifat deskriptif yaitu penelitian yang menggambarkan data informasi yang berdasarkan dengan kenyataan (fakta) yang diperoleh di lapangan.Penelitian deskriptif sendiri merupakan penelitian yang paling dasar. Ditunjukkan untuk mendeskripsikan atau menggambarkan fenomena yang ada, baik fenomena yang bersifat ilmiah ataupun rekayasa manusia. Penelitian ini mengkaji bentuk, aktivitas, karakteristik, perubahan, hubungan, kesamaan dan perbedaannya dengan fenomena lain. Deskriptif kualitatif dalam penelitian ini digunakan untuk mengembangkan teori yang dibangun melalui data yang diperoleh di lapangan (Sukmadinata, 2009:60).

\section{A. Metode Pengumpulan Data}

Metode pengumpulan data merupakan usaha untuk mengumpulkan bahan-bahan yang berhubungan dengan penelitian yang berupa data, fakta, gejala, maupun informasi yang sifatnya valid, dapat dipercaya dan obyektif ( sesuai dengan kenyataan).

1. Observasi

Metode observasi adalah metode pengumpulan data yang digunakan untuk menghimpun data penelitian melalui pengamatan dan penginderaan (Bungin, 2007:115)

\section{Wawancara}

Merupakan proses memperoelh keterangan untuk tujuan penelitian dengan tanya jawab sambil bertatap mukaantara pewawancara dengan informan atau orang yang diwawancarai, dengan atau tanpa menggunakan pedoman wawancara (Bungin, 2007: 108). 


\section{Dokumentasi}

Dokumentasi adalah suatu cara yang digunakan untuk memperoleh data dan informasi dalam bentuk buku, arsip, dokumen, tulisan angka dan gambar yang berupa laporan serta keterangan yang dapat mendukung penelitian..

\section{Teknik Analisis Data}

Setelah data diperoleh maka langkah selanjutnya ialah mengolah data yang telah didapat. Pada tahap ini dilakukan analisis terhadap data yang telah didapat. Dalam penelitian ini penulis mengolah data melalui beberapa tahap, yaitu:

1. Reduksi data

Data yang diperoleh melalui observasi, wawancara dan pendokumentasian dicatat dan dikelompokkan. Data yang diambil melalui observasi dan dokumnetasi dikelompokkan sehingga dapat diketahui data mana yang relevan atau tidak dengan kajian yang diteliti. Data yang diambil melalui wawancara pun dikelompokan, sehingga akan terlihat perbedaan atau kesamaan jawaban dari informan yang diwawancarai.

\section{Penyajian Data}

Setelah data reduksi penulis akan melakukan penyajian data. Data ini akan disajikan dalam bentuk teks bersifat naratif. Penulis akan menerangkan atau menceritakan hasil penelitian dengan bentuk penjabaran kata-kata.

\section{Penarikan Kesimpulan}

Kesimpulan adalah suatu pernyataan umum dan logis yang ditarik dari beberapa kasus, dan menunjukan pola yang menggambarkan ciri-ciri kasus tersebut (Prasetya, 2006:102). Data yang telah disajikan kemudian dimbil kesimpulan dan dijabarkan dalam bentuk naratif. Kesimpulan ini merupakan jawaban atas rumusan masalah dari penelitian.

\section{Triangulasi Data}

Triangulasi adalah teknik pengumpulan data yang bersifat menggabungkan dari berbagai teknik pengumpulan data dan sumber data yang telah ada (Sugiyono, 2014:241). Teknik yang dimaksud berupa wawancara, observasi dan dokumnetasi untuk sumber data yang sama secara serentak (Sugiyono, 2016: 241). 


\section{HASIL DAN PEMBAHASAN}

1. Perilaku pencarian informasi pemakai tunanetra dalam mengakses informasi melalui layanan braille corner di Dinas Kearsipan dan Perpustakaan Kota Jambi

Wilson menggabungkan kedua model perilaku pencarian informasi yang dikemukakan oleh Ellis dan Khulthau yang masing-masing tahapannya terbagi dalam kegiatan mencari informasi. Tahapan pencarian informasi dimulai dari ketidakpastian hingga menuju pemahaman. Model tersebut dapat diuraikan pada gambar dibawah ini:

\section{Gambar 2.1 Pencarian Perilaku Informasi}

Pencarian Perilaku Informasi tersebut dapat dijelaskan pada tabel 2.1 berikut:

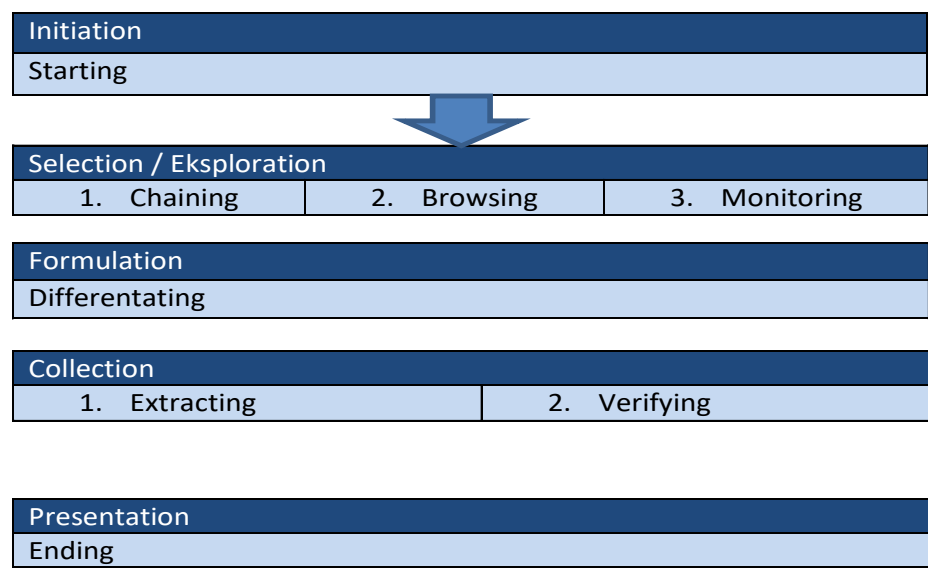

\section{Initiation}

Pada awalnya seseorang mengalami masalah yang tidak dapat diselesaikan sendiri hal itu karena kurangnya pengetahuan yang dimiliki sehingga seseorang tidak dapat memecahkan masalah yang dihadapinya. Pada tahapan ini muncul kesadaran seseorang akan adanya kebutuhan informasi. Dalam tahap ini dapat diketahui bagaimana tahap awal yang digunakan oleh pemakai dalam mencari informasi yang dibutuhkan.

Kesimpulan yang didapat peneliti dari pemustaka tunanetra tersebut adalah informan melakukan pencarian informasi berdasarkan latar belakang yang berbeda. Sehingga ada yang melakukan pencarian informasi karena untuk menambah pengetahuan, ada juga yang digunakan agar tidak ketertinggalan informasi serta agar bisa memanfaatkan fasilitas yang tersedia. 


\section{Starting}

Dengan adanya perasaan akan kurangnya pengetahuan, menyesuaikan dengan orang yang tidak mempunyai kebutuhan khusus serta tidak ketinggalan informasi terbaru dan untuk memanfaatkan fasilitas perpustakaan. Seseorang memutuskan untuk memulai pencarian informasi. Pada tahapan inilah dimulainya kegiatan pencarian informasi.

Dari hasil wawancara tersebut, peneliti dapat mengambil kesimpulan bahwa dalam melakukan pencarian informasi sebagaian besar dengan bertanya melalui petugas layanan perpustakaan, namum ada juga pemustaka yang langsung mengakses informasi di rak tanpa bertanya kepada petugas layananan. Dan dari wawancara tersebut dapat pula disimpulkan dari pemustaka tunanetra yang berkunjung tersebut belum mengenal katalog.

\section{Selection/Eksporation}

Seseorang akan merasa siap untuk melakukan pencarian dengan selektif, siap untuk melakukan penelusuran dengan teliti. Pada tahap eksploration seseorang akan merasakan penasaran yang mendalam sehingga akan menimbulkan kegiatan pencarian yang lebih mendalam. Pada tahapan ini sering terjadi kesulitan karena terkadang seseorang yang mencari informasi tidak mampu untuk menyatakan dengan tepat informasi yang dibutuhkannya kepada petugas lembaga informasi.

Kesimpulan dari wawancara adalah seorang informan akan mencari mencari di internet jika tidak menemukan informasi yang tersedia, ada juga informan yang bertanya kepada pustakawan mengenai informasi sejenis yang butuhkan, serta meminta rekomendasi koleksi lain jika tidak ada di perpustakaan tersebut.

\section{a. Chaining}

Individu mulai menghubungkan informasi yang dicari dengan informasi yang didapatkan dari satu sumber pencarian.

Hasil dari wawancara diatas adalah informasi yang sering di akses di layanan braille corner perpustakaan kota jambi menurut DI adalah buku fiksi seperti buku cerita dan novel. Namun hal yang berbeda dilakukan oleh KJP dimana ia lebih banyak mengakases buku pelajaran, sedangkan informan SA lebih suka mengakses buku pelajaran dan kitab suci. hal ini memberikan data bahawa setiap pemustaka yang berkunjung memiliki persamaan dan perbedaan tujuan dalam mengakases informasi. 


\section{a. Browsing}

Kegiatan meramba yaitu suatu kegiatan mencari informasi dari satu sumber ke sumber lain sehingga secara tidak langsung ia mulai melakukan strukturisasi informasi yang digunakan. Kegiatan ini dapat dilakukan dengan mencari pada tema yang sama, mirip ataupun dapat dicari melalui daftar pustaka pada suatu bacaan dengan ini akan mendapatkan beragam informasi.

Kesimpulan yang didapat peneliti dari wawancara tersebut adalah beberapa pemustaka mendapatkan informasi dengan dibantu oleh pustakawan. Lalu, jika pemustaka tidak menemukan informasi yang dicari di layanan Braille Corner maka pustakawan akan merekomendasikan koleksi yang lain serta merekomendasikan ke perpustakaan lain yang bisa membantu pemustaka tersebut dalam menelusur informasi.

\section{Monitoring}

Merupakan kegiatan pengawasan, dimana seseorang mencari perkembangan informasi yang terbaru agar informasi yang dicarinya masih dalam informasi terkini

Kesimpulan dari peneliti dari hasil wawancara tersebut adalah pustakawan mempunyai peranan yang sangat penting dalam memberikan layanan kepada pemustaka tunanetra, karena mereka merupakan pemustaka yang berkebutuhan khusus. Mulai dari menelusur informasi terbaru serta menggunakan koleksi yang ada di perpustakaan tersebut.

\section{Formulation}

Pada tahapan ini kepercayaan seseorang mulai meningkat, dengan informasi yang dicari pola pikir seseorang menjadi lebih jelas dengan memfokuskan pikiran pada pemecahan masalah yang dihadapi, munculnya perasaan pasti.

Kesimpulan dari wawancara di atas yang peniliti dapatkan adalah pemustaka menggunakan buku braille dan dibantu oleh pustakawan.

Hal ini juga diperkuat oleh pernyataan pustakawan mengenai ketersediaan koleksi buku braille. Hal tersebut diambil dari hasil wawancara atas pertanyaan saran apa agar informasi yang ada di perpustakaan dapat di manfaatkan dengan baik oleh pemustaka yang datang ke layanan braille corner perpustakaan .

Dari hasil wawancara tersebut dapat disimpulkan bahwa masih koleksi yang terus bertambah namun tidak tersedia dalam bentuk elektronik yang lebih memudahkan pemustaka. 
Kesimpulan yang peneliti dapatkan dari wawancara tersebut adalah pustakawan mempunyai peranan yang sangat penting dalam mencari informasi yang dibutuhkan oleh pemustaka tunanetra. Pustakawan membantu baik dalam mengakses informasi, menggunakan koleksi tersebut serta memberikan rekomendasi jika informasi yang dibutuhkan tidak tersedia di perpustkaan tersebut.

\section{Differentating}

Kegiatan menyaring, memilih informasi yang telah didapatkan, sehingga individu dapat mengetahui perbedaan dari informasi yang telah didapatkan nya.

Kesimpulan yang dapat peneliti ambil dari wawancara tersebut adalah pemustaka membutuhkan media elektronik untuk memudahkan dalam mengakses informasi namun media elektronik tersebut belum tersedia di perpustakaan tersebut.

\section{Collection}

Pada tahapan ini interaksi individu dan sumber informasi lebih efektif dan efisien, mengumpulkan informasi yang terfokus pada masalah yang dicari.

Dari hasil wawancara tersebut dapat disimpulkan ada pemustaka yang mengakses informasi sekitar 1 jam, namun ada yang lebih efisien yaitu sekitar 30 menit, namun ada juga pemustaka yang mengakses informasi dengan relatif lama yaitu membutuhkan waktu sekitar 2 jam.

\section{Extracting}

Merangkum, memeriksa kembali satu sumber yang terpilih untuk mengambil informasi yang dianggap penting, mengelompokkan bahan-bahan yang dicari.

Kesimpulan yang bisa didapatkan dari wawancara tersebut adalah sebagian besar pemustaka tunanetra menggunakan buku braille sebagai alat telusur untuk mencari informasi , serta bertanya kepada pustakawan untuk membantu dalam proses penelusuran memperoleh informasi yang diinginkan nya.

Pustakawan juga memberikan fasilitas seperti memberikan layanan peminjaman koleksi buku braille jika dibutuhkan oleh pemustaka untuk membantu pemustaka tunanetra dalam memperoleh informasi yang didapatkan”. Seperti dalam petikan wawancara dengan DE yang 
mengatakan : "Perpustakaan memberikan layanan peminjaman buku Braille bagi pemustaka yang membutuhkan.",

Kesimpulan yang didapatkan peneliti dari hasil wawancara tersebut adalah dengan adanya fasilitas peminjaman yang dilakukan oleh pihak perpustakaan dapat membantu pemustaka tunanetra dalam memperoleh informasi.

\section{Verifying}

Kegiatan pengujian ketepatan apakah informasi yang dicari tepat dengan informasi yang didapatkan.

Kesimpulan oleh peniliti yang didapatkan dari wawancara tersebut adalah kemudahan dalam mengakases informasi yang dibutuhkan oleh pemustaka tunanetra yaitu dengan bantuan yang diberikan oleh petugas di layanan tersebut.

\section{Presentation}

Pada tahapan ini pencarian telah selesai akan menimbulkan perasaan puas akan hasil pencarian, merasa jelas akan informasi yang didapatkan, informasi yang telah didapatkan dapat digunakan dan dipresentasikan.

Kesimpulan yang didapat peneliti dari pemustaka tunanetra tersebut adalah informan melakukan pencarian informasi berdasarkan latar belakang yang berbeda. Sehingga ada yang melakukan pencarian informasi karena untuk menambah pengetahuan, ada juga yang digunakan agar tidak ketertinggalan informasi serta agar bisa berbagi informasi dengan orang lain.

\section{Ending}

Tahapan bahwa telah selesainya proses pencarian informasi individu mengakhiri pencariannya.

Kesimpulan oleh peniliti yang didapatkan dari wawancara tersebut adalah informan mengakhiri pencarian informasi dengan mencek kembali catatan serta mengembalikan koleksi ketempat semula yaitu dirak.

\footnotetext{
${ }^{1}$ Wawancara dengan Dian Ekawati, SS, petugas layanan, tanggal 3 Maret 2020
} 
Kendala-Kendala yang dihadapi pemustaka tunanetra dalam mengakses informasi di Dinas Kearsipan dan Perpustakaan Kota Jambi

a. Kurangnya alat penelusuran elektonik

Dari hasil wawancara tersebut kurangnya alat penelusuran elektronik dapat mengakibatkan sulitnya tunanetra dalam menemukan informasi yang mereka butuhkan.

b. Belum tersedianya katalog elektronik maupun katalog manual

Katalog sangat membantu dalam proses pencarian informasi sehingga dengan tidak tersedianya hal tersebut mengakibatkan lamanya proses penelusuran atau mengakibatkan proses pencarian informasi menjadi kurang efektif.

c. Penempatan koleksi yang tidak pada tempatnya

Kesimpulan yang dapat peneliti ambil dari hasil wawancara tersebut, terdapat beberapa kendala antara lain sebagai berikut:

Kendala utama adalah kurangnya fasilitas yaitu tidak tersedia alat penelusur informasi dalam bentuk media elektronik, kendala yang selanjutnya adalah tidak tersedia nya katalog yang mempermudah dalam penelusuran informasi, serta keadaan koleksi yang berubah-ubah.

1. Solusi yang diberikan pustakawan untuk mengatasi kendala pemustaka dalam mengakses informasi melalui layanan braille corner di Dinas Kearsipan dan Perpustakaan Kota Jambi:

2. a. Membantu mencari koleksi di rak

b. Membantu menelusur informasi di internet

\section{E. KESIMPULAN}

Berdasarkan dari hasil penelitian mengenai Perilaku Pencari Informasi Layanan Braille Corner Pemustaka Tunanetra di Dinas Kearsipan Dan Perpustakaan Kota Jambi, maka kesimpulan yang dapat diambil dari penelitian tersebut adalah sebagai berikut: Pencari Informasi Layanan Braille Corner Pemustaka Tunanetra Di Dinas Kearsipan Dan Perpustakaan Kota Jambi sangat dipengaruhi oleh petugas layanan Braille Corner. Jenis informasi yang sering diakses oleh pemustaka tunanetra di Dinas Kearsipan Dan Perpustakaan Kota Jambi adalah koleksi tercetak Braille. Sumber informasi yang sering di gunakan oleh pemustaka tunanetra dalam penelusuran informasi di Dinas Kearsipan Dan Perpustakaan Kota Jambi adalah dengan menggunakan daftar koleksi perpustakaan, serta pemustaka bertanya kepada petugas layanan dalam penelusuran informasi. Kendala yang dihadapi pemustaka tunanetra seperti tidak tersedia nya komputer bicara dan alat 
pemutar CD. Berdasarkan kesimpulan yang diperoleh, maka peneliti memberikan saran yang sekiranya dapat dijadikan sebagai bahan pertimbangan oleh Dinas Kearsipan Dan Perpustakaan Kota Jambi untuk memberikan pelayanan yang prima bagi pemustaka tunanetra untuk masa yang akan datang. Adapun saran tersebut adalah sebagai berikut: Dinas Kearsipan Dan Perpustakaan Kota Jambi perlu adanya penambahan petugas layanan untuk layanan Braille Corner sehingga jika ada pemustaka yang membutuhkan bantuan petugas dapat memberikan layanan yang optimal. Dinas Kearsipan Dan Perpustakaan Kota Jambi sebaiknya mengusahakan adanya fasilitas komputer bagi pemustaka tunanetra serta tersedianya DTB (Digital Talking Book, sehingga untuk mendapatkan informasi pemustaka tinggal mendengarkan informasi yang diinginkannya). Serta Dinas Kearsipan Dan Perpustakaan Kota Jambi perlu mengusahakan adanya katalog braille untuk memudahkan dalam penelusuran informasi. Dinas Kearsipan Dan Perpustakaan Kota Jambi memberikan pelatihan maupun kegiatan usur education kepada pemustaka tunanetra agar pemustaka lebih terlatih dalam menggunakan layanan Braille Corner secara maksimal sehingga pemustaka tunanetra bisa lebih efektif dan efisien dalam menelusur informasi.

\section{DAFTAR PUSTAKA}

Arikunto, Suharsimi. 2000. Manajemen Penelitian, Jakarta: Rineka Cipta Astari , Kurnia. 2018. Skripsi: "Perilaku pencarian informasi pemustaka tunanetra dalam mengakses informasi di perpustakaan SAPDA Yogyakarta" Yogyakarta: UIN Sunan Kalijaga Yogyakarta

Anshori, Ricky. 2013. Skripsi: "Perilaku pencarian informasi pemakai pada layanan perpustakaan Tunanetra Yayasan Mitra Netra Jakart”. Semarang: Universitas Diponegoro Bungin, Burhan. 2007. Penelitian Kualitatif. Jakarta: Kencana

Bikna Tariang, Laloo. 2000. Informasi needs, Informasi seaking behavior dan Users. New Delhi : Ess Publication

Departemen Agama RI. 2007. Al-Qur'an dan Terjemah: Special For Woman. Bandung : Sygma Examedia Arkanleema

Furchan ,Arif. 1992. Pengantar Metodologi Penelitian Kualitatif. Surabaya: Usaha Nasional

Gunawan , Imam. 2013 Metode Penelitian Kualitatif, Teori Dan Praktik, Jakarta: Bumi Aksara

Hamalik, Oemar. 1993 Pengelolaan Sistem Informasi. Bandung : Tri genda Irawan ,Prasetya. 2006. penelitian kualitatif dan kuantitatif untuk ilmu-ilmu sosial. Jakarta: Departemen Ilmu Administrasi FISIP UI 
Luthfiyah ,Muh. Fitrah. 2017. Metodologi penelitian; Penelitian kualitatif, Tindakan Kelas dan Studi Kasus. Jawa Barat: Jejak

Moleong, J. Lexy. 2012 Metodologi Penelitian Kualitatif, Bandung: Remaja Rosdakarya Rahayuningsih. 2007. Pengelolaan Perpustakaan. Yogyakarta: Graha Ilmu

Sutabri. 2005. Sistem Informasi Manajemen . Yogyakarta : Andi

Sukmadinata , Nana, Syaodih. 2009. Metode Penelitian Pendidikan.Bandung: Remaja Rosdakarya

Sugiyono. 2016.Metode Penelitian Kuantitatif, Kualitatif Dan $R \&$ D. Bandung: Elfabeta

Thomas, D. Wilson. 2000 Human information BEHAVIOR. Informing science :2000

Undang-Undang Nomor 43 Tahun 2007 tentang Perpustakaan. 2010. Jakarta: Diperbanyak Penerbit Media

Yusup, M. Pawit. 2010. Teori dan Praktiks Penelususran Informasi: Informasi Retrieval. Jakarta: Preda Media Group 